\begin{tabular}{|l|l|l|}
\hline \multicolumn{2}{|c|}{ PublisherInfo } \\
\hline \hline PublisherName & $:$ & BioMed Central \\
\hline \hline PublisherLocation & $:$ & London \\
\hline \hline PublisherImprintName & $:$ & BioMed Central \\
\hline \hline
\end{tabular}

\title{
Did bitter tasters do better?
}

\begin{tabular}{|l|l|l||}
\hline \multicolumn{2}{|c|}{ ArticleInfo } \\
\hline \hline ArticleID & $:$ & 5028 \\
\hline \hline ArticleDOI & $:$ & $10.1186 /$ gb-spotlight-20050727-01 \\
\hline \hline ArticleCitationID & $:$ & spotlight-20050727-01 \\
\hline \hline ArticleSequenceNumber & $:$ & 91 \\
\hline \hline ArticleCategory & $:$ & Research news \\
\hline ArticleFirstPage & $:$ & 1 \\
\hline \hline ArticleLastPage & $:$ & 3 \\
\hline \hline & & RegistrationDate : 2005-7-27 \\
\hline ArticleHistory & $:$ & OnlineDate \\
\hline \hline ArticleCopyright & $:$ & BioMed Central Ltd2005-7-27 \\
\hline \hline ArticleGrants & $:$ & \\
\hline \hline ArticleContext & $:$ & 130595511 \\
\hline \hline
\end{tabular}




\section{Ishani Ganguli}

Email: iganguli@the-scientist.com

An improved ability to distinguish the bitter taste of natural toxins in foods may have made a difference in the survival of early humans as they radiated out of Africa, according to a genetic analysis by researchers led by a group at University College London, appearing in the July 26 issue of Current Biology. The new study suggests that a particular allele for the G protein-coupled taste receptor TAS2R16-which mediates the response to bitter cyanogenic glycosides found in many food plants-has been favored by human evolution.

"There is a general understanding that higher primates and humans in particular are losing some of their sensory capabilities because we have replaced sensory perception with other means of protecting ourselves-cooking food, for instance, or even changing diet," said coauthor Nicole Soranzo.

However, these results suggest that there is more to the evolutionary story, said John Glendinning, of Barnard College in New York, who did not participate in the study. "This is the first study that's really looked seriously at the functional consequences of one of these [receptors] as it relates to bitter taste ecology," Glendinning told The Scientist.

The authors sequenced the entire coding region and part of the 5' and 3' untranslated regions of the TAS2R16 gene in nearly 1000 individuals representing 60 populations worldwide. Out of the 17 variable sites, they focused on amino acid site 172 , which tends to be lysine $(\mathrm{K})$ or asparagine $(\mathrm{N})$ and lies in an extracellular loop domain of the receptor. Based on comparisons with nonhuman primate sequences, they estimated that the $\mathrm{K}$ allele was ancestral and that the $\mathrm{N}$ allele emerged between 77,751 and 685,380 years ago, just before early humans were leaving Africa.

When the authors looked at the global distribution of the alleles, they found "a fairly unusual pattern of variation," according to Stephen Wooding at the University of Utah, who did not participate in the study. The $\mathrm{N}$ form of the gene is present in $90 \%$ of non-Africans, while the ancestral $\mathrm{K}$ form predominated in areas of Africa with endemic malaria, where only 15.6\% carried the N172 allele. Such a high frequency of derived allele is "a signature of positive selection," Soranzo told The Scientist, and statistical tests like the Fay and Wu test on these data confirmed this hypothesis.

To test the alleles' phenotypic effects, the authors used in vitro calcium imaging and found that those cells expressing the N172 allele were more sensitive to bitter compounds. These results suggest that the allele became more prevalent in non-African populations to protect them from toxins in plants they might have encountered outside the continent, Dennis Drayna, of the National Institutes of Health, who did not participate in the study, told The Scientist via E-mail.

"As these populations move out, if they start encountering the cyanogenic glycoside [containing] plants, then the ones that have the receptor with the higher binding affinity may be more likely to taste the cyanogenic glycosides and stop feeding before they kill themselves," Glendinning said.

The fact that the $\mathrm{K}$ ancestral form is still prevalent in African populations, and particularly in Central Africa, could be explained by a selective advantage against malaria, the authors suggest. Previous work has linked chronic low-level ingestion of cyanide with lowered malaria risk, with the idea that increased levels of cyanide in the bloodstream could make humans less hospitable hosts for the parasite, 
Glendinning said. In the current study, living in lower-malaria-risk countries was correlated with a higher frequency of the less taste-sensitive allele.

"One could speculate that the reduced sensitivity towards this compound could help to increase intake of cyanide in the diet, and this in turn could have an evolutionary advantage by protecting against malaria infection," Soranzo said. The connection is "completely speculative at this point" but "worth exploring," she said.

These findings present a different evolutionary story-one of "local adaptation," according to Wooding-than the other well-characterized bitter taste receptor: TAS2R38, for PTC. The allele distribution for TAS2R38 demonstrates balancing selection, maintaining two distinct alleles in populations, which may allow a greater range of bitter taste recognition, according to a paper Wooding and Drayna published last year.

According to Glendinning and Drayna, experiments must now be conducted on humans to confirm the functional effect of the variants. "It's a big jump from a...cell expressing a particular G proteincoupled receptor [to] the human brain," Glendinning said. Coauthor Bernd Bufe, of the German Institute of Human Nutrition, said the team will use "taste tests to determine threshold levels" as he did in a previous paper.

"One of the very nice things about this study is that it suggests a very concrete hypothesis that might be tested in populations where malaria is present," Wooding told The Scientist. "It would be very interesting to return to those populations and find out whether people who are more or less sensitive to these compounds really do eat more of these plant compounds that protect them from malaria."

\section{References}

1. N. Soranzo et al., "Positive selection on a high-sensitivity allele of the human bitter-taste receptor TAS2R16," Current Biology, 15:1257-65, July 26, 2005., [http://www.current-biology.com/]

2. Nicole Soranzo, [http://popgen.biol.ucl.ac.uk/people/ns/nicole_home.html]

3. John I. Glendinning, [http://www.barnard.edu/biology/faculty.html]

4. Stephen Wooding, [http://www.xmission.com/ wooding/]

5. Dennis Drayna, [http://www.nided.nih.gov/research/scientists/draynad.asp]

6. F. Jackson et al., "Two evolutionary models for the interactions of dietary cyanogens, hemoglobin S, and falciparum malaria." Am J. Human Biology, 2(5):521-532, May 1990., [http://www3.interscience.wiley.com/cgi-bin/abstract/110504066/ABSTRACT]

7. S. Wooding et al., "Natural selection and molecular evolution in PTC, a bitter-taste receptor gene," Am J Hum Genet, 74(4):637-46, April 2004.

8. B. Bufe et al., "The molecular basis of individual differences in phenylthiocarbamide and propylthiouracil bitterness perception," Current Biology, 15(4):322-7, February 2005. 